\title{
Hairy Nightshade as a Potential Potato leafroll virus (Luteoviridae: Polerovirus) Inoculum Source in Pacific Northwest Potato Ecosystems
}

\author{
R. Srinivasan and J. M. Alvarez
}

Department of Plant Soil and Entomological Sciences, University of Idaho, Aberdeen R\&E Center, Aberdeen 83210. Accepted for publication 27 May 2008.

\begin{abstract}
Srinivasan, R., and Alvarez, J. M. 2008. Hairy nightshade as a potential Potato leafroll virus (Luteoviridae: Polerovirus) inoculum source in Pacific Northwest potato ecosystems. Phytopathology 98:985-991.

Hairy nightshade, Solanum sarrachoides, is a solanaceous weed found abundantly in Pacific Northwest potato ecosystems. It serves as a reservoir for one of the important potato viruses, Potato leafroll virus (PLRV) (Luteoviridae: Polerovirus), and its most important vector, the green peach aphid, Myzus persicae (Homoptera: Aphididae). Laboratory research indicated an increased green peach aphid settling and performance on $S$. sarrachoides than on potato. It also revealed that green peach aphids

conducted at Kimberly, Idaho. Two inoculum sources, PLRV-infected potato and PLRV-infected $S$. sarrachoides, were compared in this trial. Green peach aphid density and temporal and spatial PLRV spread were monitored at weekly intervals. Higher densities of green peach aphids were observed on plots with $S$. sarrachoides and inoculum sources (PLRVinfected $S$. sarrachoides and potato) than on plots without $S$. sarrachoides and inoculum sources. PLRV infection in plots with PLRV-infected $S$. sarrachoides was similar to or slightly higher than in plots with PLRVinfected potato as an inoculum source. Temporal and spatial PLRV spread was similar in plots with either inoculum source. Thus, $S$. sarrachoides is as efficient as or a better PLRV inoculum source than potato.
\end{abstract} transmitted PLRV more efficiently from $S$. sarrachoides to potato than from potato to potato. To test the efficiency of $S$. sarrachoides as an inoculum source in the field, a two season (2004 and 2005) trial was
Additional keywords: noxious weed.
Potato leafroll virus (PLRV) (Luteoviridae: Polerovirus) is one of the most important viruses that affect the potato, Solanum tuberosum L. crop in the United States and worldwide $(18,30)$. PLRV is tissue specific (phloem-restricted) and causes characteristic rolling of leaves, chlorosis, and stunting of infected plants. The nature and severity of PLRV symptoms depend on several factors such as the virus strain, the potato variety, the time and source of infection, and the environmental conditions (3). Some potato cultivars such as Russet Burbank, which is the predominant cultivar in Idaho, are susceptible to PLRV-induced tuber necrosis. Losses due to tuber necrosis could be up to $100 \%$ (23). The potato colonizing green peach aphid, Myzus persicae (Sulzer) (Homoptera: Aphididae), is the most important PLRV vector. It transmits PLRV in a persistent, circulative, and nonpropagative manner $(17,22)$.

Hairy nightshade, $S$. sarrachoides (Sendtner) is a widely prevalent annual solanaceous weed in Pacific Northwest (PNW) potato ecosystems. This weed acts as an alternate host for PLRV and its vector, the green peach aphid, $M$. persicae $(2,3,35,37)$. It is very difficult to control this weed as it is closely related to potato to permit selective herbicidal control and also due to its phenomenal reproductive capacity $(5,11,25,26,28,29)$.

Higher densities of green peach aphid were commonly observed on $S$. sarrachoides than on adjacent potato plants in Idaho's potato ecosystems $(2,3)$. Our laboratory studies showed that aphids exhibited increased preference for $S$. sarrachoides over potato and more efficiently transmitted PLRV from $S$. sarrachoides to potato than from potato to potato $(2,32)$.

Corresponding author: J. M. Alvarez; E-mail address: jalvarez@uidaho.edu

doi:10.1094/PHYTO-98-9-0985

(c) 2008 The American Phytopathological Society
Due to its vector and virus harboring abilities, and its ubiquity in potato ecosystems, $S$. sarrachoides could potentially act as an inoculum source both outside as well as inside the crop matrix and affect vector distribution, movement, and ultimately disease spread.

Aphid movement from outside or within field inoculum sources contributes to the primary virus spread in a crop field. Aphids have also been known to preferentially settle on virus-infected plants and then subsequently move to uninfected plants due to poor nutrition and/or overcrowding $(12,14,16,19,21,27,34,40)$. We observed preferential settling of winged and wingless green peach aphids on PLRV-infected $S$. sarrachoides plants under laboratory conditions (32), and these findings could have epidemiological implications such as viral-acquisition, transmission, and virus spread. Although we have previously demonstrated that green peach aphid preferentially landed on $S$. sarrachoides than on potato plants early in the summer, so far no study has evaluated the ability of $S$. sarrachoides as a PLRV inoculum source in the field.

In order to attest the hypothesis that $S$. sarrachoides could potentially play an important role in green peach aphid population build-up and PLRV spread in potato ecosystems, field trials were conducted during the summers of 2004 and 2005.

\section{MATERIALS AND METHODS}

This experiment was conducted at the University of Idaho, Kimberly Research and Extension Center, Kimberly, ID. The experiment included three treatments: (i) S. sarrachoides PLRVinfected, (ii) potato PLRV-infected, and (iii) S. sarrachoides uninfected, and a control (uninfected potato plants), replicated four times in a completely randomized block design. Machine cut Generation 2 (G2) seed pieces (cv. Russet Burbank) weighing 
approximately $57 \mathrm{~g}$ each were planted the first week of May in 2004 and 2005.

Field design. Individual treatment plots consisted of 14 rows ( $0.91 \mathrm{~m}$ row spacing) wide by $12.19 \mathrm{~m}$ for an area of $156.08 \mathrm{~m}^{2}$ (Fig. 1) and a total of 574 plants per plot. On both years, the center potato plants of each plot were replaced by 10 plants of each treatment (Fig. 1) 6 to 7 weeks after planting. The treatment placement assumed a randomized complete block design.

Preparation of treatments (host plants and aphids). $S$. sarrachoides. Seeds were obtained from J. S. Hutchinson, University of Idaho Weed Scientist, Aberdeen R\&E Center. The seeds were sprouted in a petri dish lined with moist filter paper, sealed with laboratory film (Parafilm, Greenwich, CT) and incubated in growth chambers kept at $25^{\circ} \mathrm{C}, 90 \%$ relative humidity (RH) for 5 to 7 days. The sprouted seeds were planted in a greenhouse in $10 \times 10 \times 15 \mathrm{~cm}$ pots with a 2:2:1 potting mix (sand/peat/ vermiculite), and 14:14:14 (N:P:K) encapsulated fertilizer, and maintained at 19 to $27^{\circ} \mathrm{C}$ with a $16 \mathrm{~h}$ photoperiod.

Potato. To ensure no initial PLRV infection in the potato propagative material, tissue culture-derived potato plantlets (cv. Russet Burbank) were obtained from the tissue culture facility at the University of Idaho, Moscow, and re-propagated using Murashige and Skoog (MS) basal salt medium with minimal organics (Sigma, St. Louis, MO). Plantlets were potted and maintained in the greenhouse under the aforementioned conditions.
Aphids. Chinese cabbage, a nonhost for PLRV, was used to culture nonviruliferous green peach aphids. A colony of nonviruliferous green peach aphids is being maintained at the University of Idaho, Aberdeen R\&E Center since 2001 in individually caged $(38 \times 21 \times 20 \mathrm{~cm}$ plexiglass cages $)$ Chinese cabbage plants in growth chambers at 21 to $26^{\circ} \mathrm{C}$ with a $14 \mathrm{~h}$ photoperiod and $90 \% \mathrm{RH}$.

PLRV inoculation. Fifty, 2-week-old uninfected $S$. sarrachoides and potato plants were inoculated using viruliferous aphids, which were fed for at least $96 \mathrm{~h}$ on PLRV-infected ground cherry, Physalis floridana (Rydberg), plants. Ten viruliferous aphids were confined with a clip cage on the ventral leaf surfaces of virus-free $S$. sarrachoides and potato plants for $96 \mathrm{~h}$, after which they were removed with a number two paint brush. Clip cages $(2.5 \mathrm{~cm}$ diameter by $1.3 \mathrm{~cm}$ deep, $3 \mathrm{~mm}$ thick) were constructed from Tygon (Mickleton, NJ) tubing and organdy cloth. Upon aphid removal, plants were placed in $100 \times 100 \times 75 \mathrm{~cm}$ chiffon cages (one treatment per cage) in the greenhouse and immediately treated with the insecticide Dibrom 8 emulsive (Amvac Chemical Corporation, Los Angeles, CA) at a rate of $29.57 \mathrm{ml}$ per $283 \mathrm{~m}^{3}$. The Dibrom treatment was repeated at weekly intervals for 3 to 4 weeks until the plants were taken to the field. Inoculated plants were tested for the presence of PLRV using double antibody sandwich enzyme-linked immunosorbent assay (DASELISA) (6) (anti-PLRV IgG and anti-PLRV IgG conjugated with

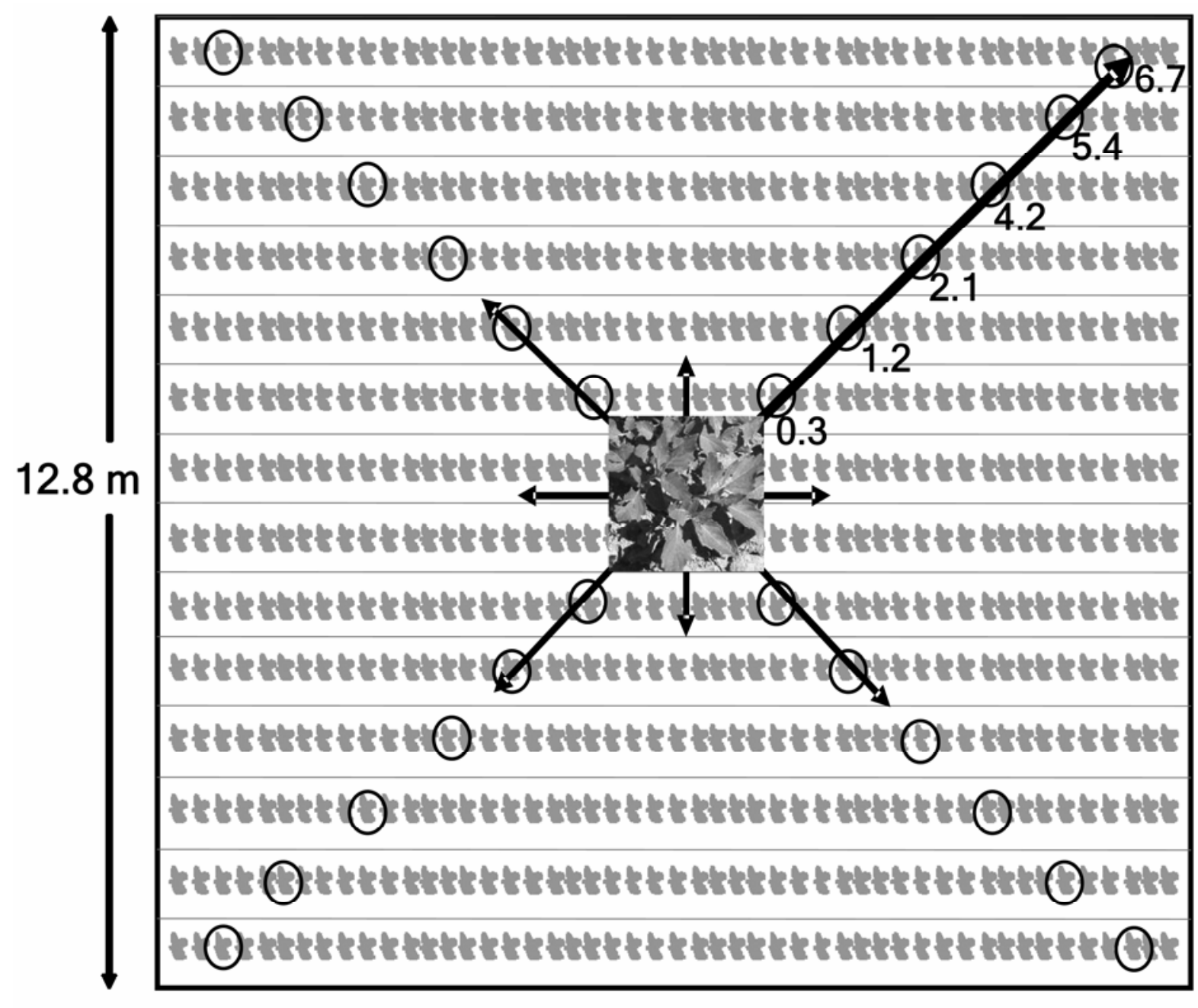

Fig. 1. Cross section of a single plot in a $4 \times 4$ complete randomized block design. The treatments were established as foci in the center of the plot. Six plants were tagged on each direction from the center of the plot at varying distances in meters. Green peach aphid counts were taken on each of the tagged plants and foliage from the same was tested for Potato leafroll virus incidence using double-antibody sandwich enzyme-linked immunosorbent assay at weekly intervals. 
Alkaline Phosphatase (BIOREBA AG, Nyon, Switzerland) 3 weeks postinoculation with suitable positive and negative controls.

Initial PLRV infection. To evaluate the initial PLRV infection level in the field before the beginning of the experiment, foliar samples from five random plants of each row included in the experiment (for a total of 1,120 plants) were collected and serologically tested by DAS-ELISA.

Plant tagging, aphid counting, foliar sampling, and serological testing. On each plot, 24 potato plants (6 on each direction from the center of the plot [foci] to each corner) at $0.3,1.2$, $2.1,4.2,5.4$, and $6.7 \mathrm{~m}$ from the placement of the treatment plants (Fig. 1) were tied to a slender green bamboo pole (Hummert, Earth City, MO) and tagged with a ribbon at the base of the plant to avoid sampling different plants after canopy closure. To initiate disease spread, 25 laboratory reared nonviruliferous green peach aphids were released in the center of each plot. Aphid counts on tagged potato plants were taken at three foliar levels (top, middle, and bottom) on weekly intervals for 8 (2004) to 10 (2005) weeks. Foliar samples were collected from the upper portion of tagged plants at weekly intervals and serologically tested using DASELISA to monitor spatial and temporal PLRV spread from the inoculum sources. The infection status of centrally located uninfected $S$. sarrachoides and potato plants was not monitored during the course of the experiment. Naturally occurring $S$. sarrachoides were weeded out weekly from planting to harvest in all the treatment plots and around the field to ensure that the $S$. sarrachoides planted in the experiment were the only ones present in the field. At harvest, six tubers from each of the tagged plants were placed in individual bags (one bag per plant; 2,304 tubers total) and stored at $45^{\circ} \mathrm{F}$ for 90 days.

Serological testing of daughter plants. After storage the harvested tubers were placed at room temperature for 2 days, cut, and planted in the greenhouse under the same conditions mentioned previously. Upon sprouting, foliar samples from the small plants were tested for PLRV infection using DAS-ELISA. All tubers were marked so the position of the mother plant on each plot could be tracked back and consequently the spatial PLRV spread from the inoculum sources could be determined.

Statistical analyses. To normalize the data, aphid count data were subjected to logarithmic transformation and treatment differences were analyzed using PROC GLM, SAS (version 9.1) (SAS Institute, Cary, NC) and treatment means were separated using Fisher's least significant difference. Orthogonal paired contrasts were used to compare treatment pairs. Spatial PLRV spread was determined as percent PLRV infection in tagged plants at each distance from the inoculum source. Temporal PLRV spread was determined as percent PLRV infection in tagged plants every week for 8 to 10 weeks after the initiation of the experiment. Linear regression using PROC REG SAS was used to correlate the aphid counts and percent PLRV infection.

\section{RESULTS}

M. persicae incidence. We observed five times more aphids on tagged plants in 2004 than in 2005 (Fig. 2A and B) despite releasing equal number of aphids on all the experimental plots at the beginning of the experiments each year. This is due to differences in densities of naturally occurring aphids in the two years. Despite differences in aphid incidence, the pattern of aphid settling was similar in both years. More aphids were recorded between early and late July (Fig. 3A and B) on plots with $S$. sarrachoides (PLRV-infected and noninfected). In 2004, total aphid settling on potato plots with $S$. sarrachoides (PLRV-infected and noninfected combined) was higher than on plots without $S$. sarrachoides $(P=0.0045)$. Aphid counts on plots with either PLRV-infected $S$. sarrachoides or uninfected $S$. sarrachoides were not different from each other $(P=0.1498)$. Potato plots with PLRV-infected potato as an inoculum source had more aphids than plots that lacked any inoculum source $(P=0.0084)$ but were not different than the plots with noninfected $S$. sarrachoides. The mere presence of uninfected $S$. sarrachoides alone increased the number of aphids in those plots compared to plots that did not have any $S$. sarrachoides $(P=0.0002)$.

As mentioned above, in 2005 the aphid settling followed a very similar pattern, with the highest number of aphids settling on potato plots with PLRV-infected $S$. sarrachoides than any other plots and more aphids settling on plots with $S$. sarrachoides than plots without the weed. However, the number of aphids was low and no statistically significant differences were observed. Aphids also showed a positional preference: in both years aphids congregated at the bottom portion of potato plants as opposed to top and middle portions of $S$. sarrachoides plants $(P<0.0001)$.

PLRV infection. The mean percentage of PLRV infection across all treatments was higher in 2004 than in 2005 (Fig. 4A and B). A linear regression analysis revealed a strong correlation $\left(r^{2}=0.9067\right)$ between green peach aphid incidence and PLRV infection. In 2004 and 2005, the mean percent PLRV infection was higher in plots with inoculum sources (PLRV-infected $S$. sarrachoides and PLRV-infected potato) than on plots without any inoculum source. In both years, the mean percentage of PLRV infection was higher in plots that had uninfected $S$. sarrachoides than in plots that did not have any S. sarrachoides. However, the difference was not significant. When comparing plots that had inoculum sources, the mean percentage of PLRV infec-

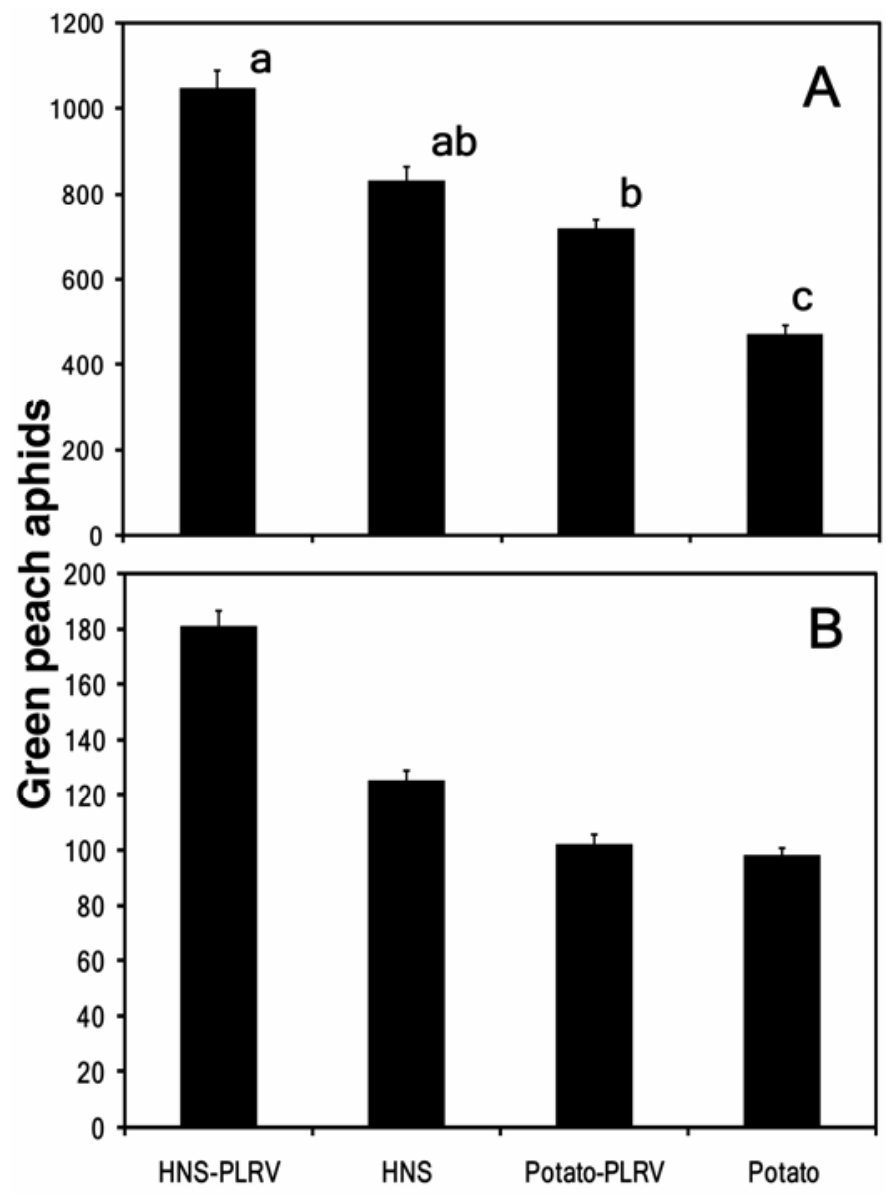

Fig. 2. Myzus persicae counts \pm standard error on potato plants in plots with and without Solanum sarrachoides and Potato leafroll virus (PLRV) infection in A, 2004 and B, 2005. Treatment differences were estimated using PROC GLM in SAS (SAS Institute, Cary, NC) and treatment means were separated using least significant difference procedure. Treatment bars with the same letters are not significantly different from each other. HNS indicates hairy nightshade, $S$. sarrachoides. 
tion in 2004 was similar in plots with PLRV-infected S. sarrachoides (mean \pm standard error $[\mathrm{SE}])(54.16 \pm 6.88)$ and PLRVinfected potato $(57.26 \pm 4.49)$; in 2005 the mean percentage of PLRV infection was higher in plots with PLRV-infected $S$. sarrachoides $(47.90 \pm 2.68)$ than in plots with PLRV-infected potato $(36.45 \pm 1.99)$. These results indicate that $S$. sarrachoides is as good as or more efficient than potato as an inoculum source (Fig. $4 \mathrm{~A}$ and $\mathrm{B})$.

Temporal PLRV spread. The initial percentage of infection in both years after plant emergence in all rows in the experiment was zero. PLRV incidence increased with time for PLRV-infected $S$. sarrachoides $\left(r^{2}=0.7983\right)$ and PLRV-infected potato $\left(r^{2}=0.7531\right)$ but not for uninfected $S$. sarrachoides $\left(r^{2}=0.3721\right)$ and potato $\left(r^{2}=0.0778\right)$. PLRV infection in tagged plants was noticed only at 2 weeks posttreatment placement and subsequently increased with time. The highest infection rates were found in the first 6 weeks after placement of inoculum sources. These rates coincided with peak aphid-densities. The infection rates increased even after 6 weeks but at a lower rate when compared to earlier weeks. The infection rates of tuber sprouts were also slightly higher than foliar-infection rates in the last week of sampling (Fig. 5A and B).

Spatial PLRV spread. PLRV incidence decreased with increase in distance from the inoculum source in both 2004 and 2005 (Fig. 6A and B). The incidence was inversely related to the distance from the center of the plot for PLRV-infected $S$. sarrachoides $\left(r^{2}=0.7872\right)$ and PLRV-infected potato $\left(r^{2}=0.7382\right)$ but not for uninfected $S$. sarrachoides $\left(r^{2}=0.2976\right)$ and potato $\left(r^{2}=0.2733\right)$. Mere presence of $S$. sarrachoides increased the PLRV spread. PLRV infection rates were higher on potato plants

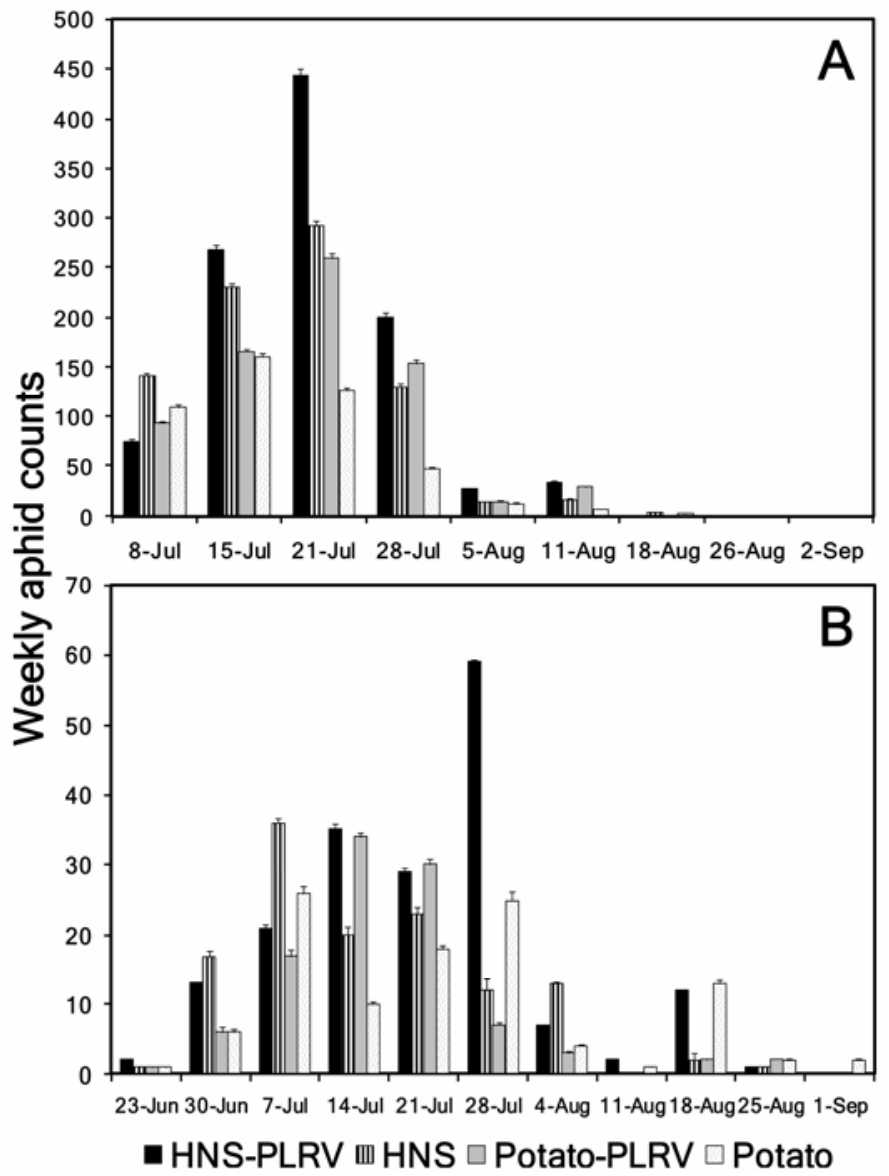

Fig. 3. Weekly Myzus persicae counts \pm standard error on potato plants in plots with Potato leafroll virus (PLRV)-infected and uninfected Solanum sarrachoides and potato. Counts were taken during an 8 to 10-week time interval between June and September A, 2004 and B, 2005. HNS indicates hairy nightshade, $S$. sarrachoides. that were closer to uninfected $S$. sarrachoides (Fig. 6A and B). The data also indicates that the initial PLRV incidence occurred on plants near to the established foci (PLRV-infected S. sarrachoides and potato), and as the season progressed there was an increased PLRV incidence on the edges of plots with uninfected aphids and potatoes (Fig. 7).

\section{DISCUSSION}

The role of annual solanaceous weeds like $S$. sarrachoides in PLRV spread has been discounted as they were presumed not to survive winter. However, annual weeds along with aphids (viviparae) were found to survive winter near canals, springs, or adjacent to heated buildings in Idaho (3). Weeds and aphids were found year round in the PNW $(9,37,38)$. Aphids surviving winters in secondary weed hosts have a higher probability to be viruliferous $(9,38,39)$. These aphids could colonize hosts such as $S$. sarrachoides early in the spring and lead to formation of new inoculum foci. Spring flights from overwintering aphids could also lead to extensive colonization of $S$. sarrachoides.

In this study, plots with $S$. sarrachoides and PLRV-infected potato as inoculum sources had more aphids than plots without any $S$. sarrachoides and inoculum sources. These observations concur with our previous laboratory results, wherein we documented aphid preference for $S$. sarrachoides and PLRV-infected plants over potato and uninfected plants (32). Additional research has also indicated an enhanced $M$. persicae performance (higher

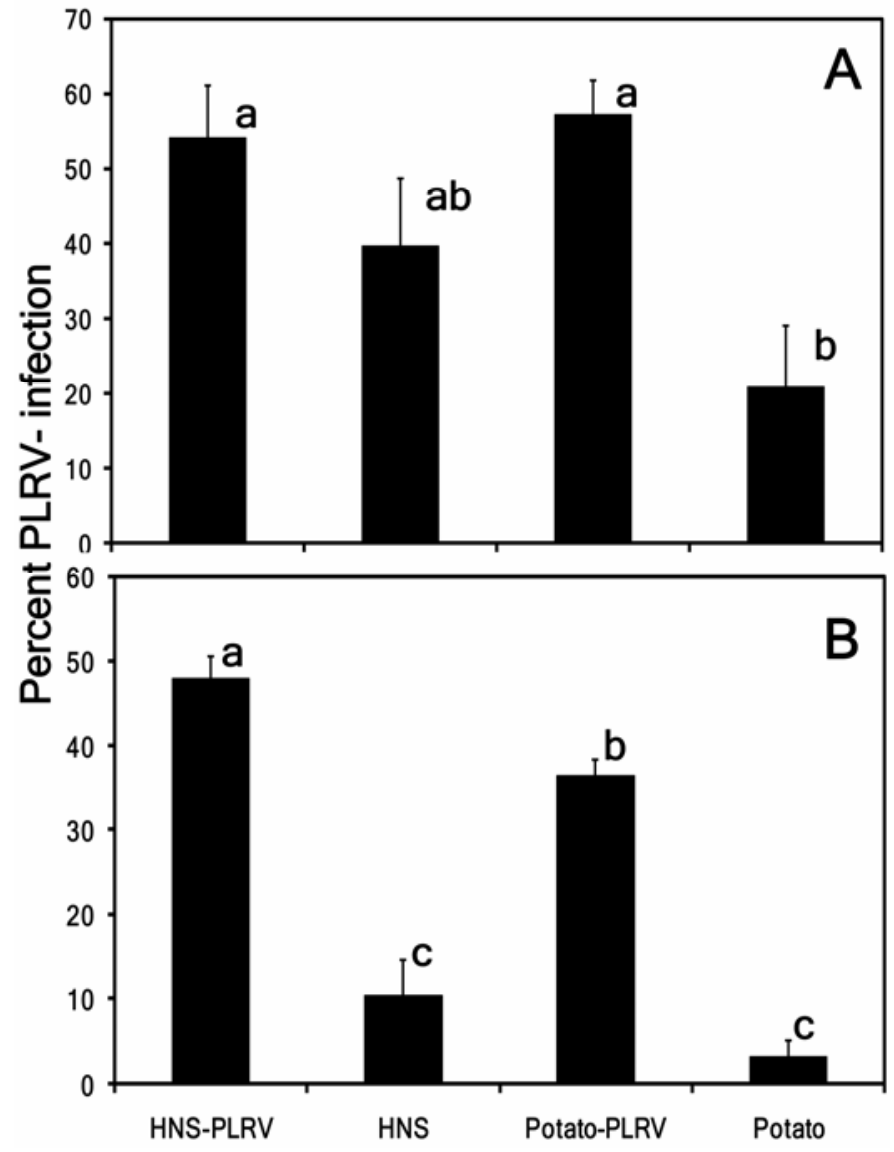

Fig. 4. Percent Potato leafroll virus (PLRV) infection \pm standard error in potato plots with and without Solanum sarrachoides. PLRV infection was determined on plant foliage sprouted from tubers harvested in A, 2004 and B, 2005. Treatment differences were estimated using PROC GLM in SAS (SAS Institute, Cary, NC) and treatment means were separated using least significant difference procedure. Treatment bars with the same letters are not significantly different from each other. HNS indicates hairy nightshade, $S$. sarrachoides. 
fecundity and longevity) on S. sarrachoides and PLRV-infected plants over potato and uninfected plants (33). This increased preference and performance on $S$. sarrachoides could explain the increased $M$. persicae incidence on $S$. sarrachoides under field conditions.

In previous laboratory experiments, aphids were able to transmit PLRV more efficiently from $S$. sarrachoides to potato than from potato to potato (2). This field study indicates that the mere presence of $S$. sarrachoides influenced the PLRV infection rates. Plots with uninfected $S$. sarrachoides patches in the middle had higher PLRV infection than plots with no $S$. sarrachoides plants. Plots with PLRV-infected $S$. sarrachoides plants also had similar or higher PLRV infection rates than plots with PLRV-infected potato. We hypothesize that increased aphid preference for $S$. sarrachoides over potato and an increased fecundity and longevity of aphids on this plant could lead to a higher PLRV transmission.

Increased $M$. persicae fecundity on $S$. sarrachoides could lead to overcrowding and dispersal to neighboring potato plants and subsequently affect PLRV spread. Aphids are generally known to move between hosts within the cropping area to avoid space and/or nutrition constraints (14).

Percent PLRV infection was higher in 2004 than in 2005, which is probably due to a four- to fivefold higher aphid density in the former year. These results reiterate that increased aphid incidence could lead to increased viral infection. The percentage of PLRV infection rate increased at a higher rate earlier in the season and then the rate of increase decreased gradually towards the end of the season. The rapid increase of PLRV infection rates earlier in the season could be due to coincident peak aphid densities and a younger physiological stage of the plants. Younger

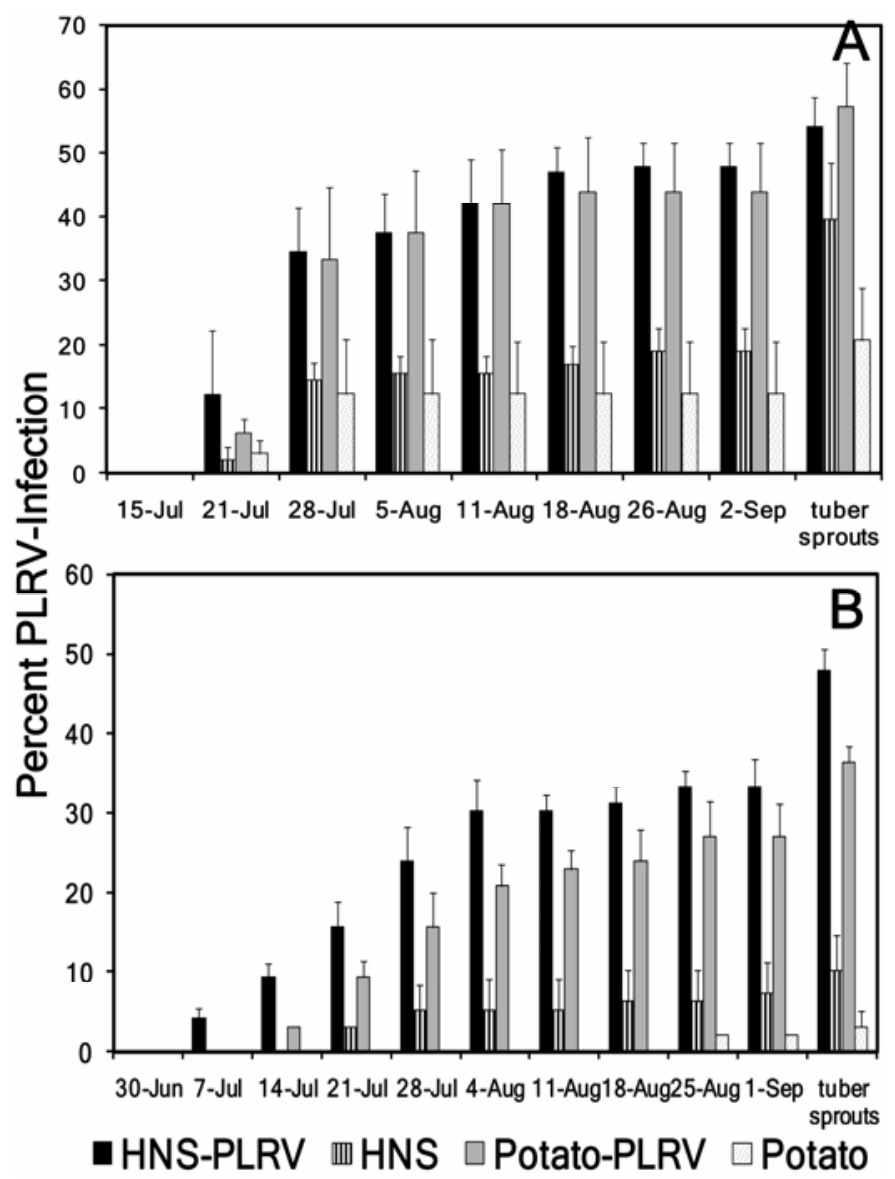

Fig. 5. Temporal Potato leafroll virus (PLRV) spread in potato plots with and without Solanum sarrachoides and PLRV infection in A, 2004 and B, 2005. Bars denote percent PLRV infection \pm standard error at weekly intervals. HNS indicates hairy nightshade, $S$. sarrachoides. plants are more susceptible to PLRV infection than mature plants, as they do not exhibit the 'mature plant resistance phenomenon' $(7,20)$.

The investigations on the spatial PLRV incidence from the inoculum foci revealed that the plants that were closer to the inoculum sources $(0.3$ and $1.2 \mathrm{~m})$ were infected at a higher rate than plants farther away from inoculum sources. Such a spatial spread seems to be very typical of Luteovirus. PLRV incidence was often detected on plants that were closer to infector plants or inoculum sources $(12,15)$. Bishop (4) monitored the spatial spread of PLRV from infected potatoes and reported that PLRV spread was greater along the rows of the infector plant than across the rows. In our experiments, PLRV infection was initially noticed at distances closer to inoculum sources and then spread farther. This sequential spatial spread indicates that the spread is predominantly aided by the movement of wingless aphids as opposed to random in-field virus spread by winged aphids. The prominent role of wingless aphids in PLRV spread has already been documented (12). However, we also noticed increased PLRV incidence on the edges of plots with noninfected $S$. sarrachoides and potatoes. These results are consistent with PLRV spread from the center together with the background of inflight of viruliferous aphids.

Our results indicate that $S$. sarrachoides can act as an efficient PLRV inoculum source and aid its spread. Due to its omnipresence in the PNW potato ecosystems, it could serve as a prominent inoculum source, and coupled with its year round aphid harboring ability, make this weed extremely undesirable. Norris and Kogan (24) cautioned that in a typical agroecosystem an alternate weed host that acts as a reservoir for a pest that

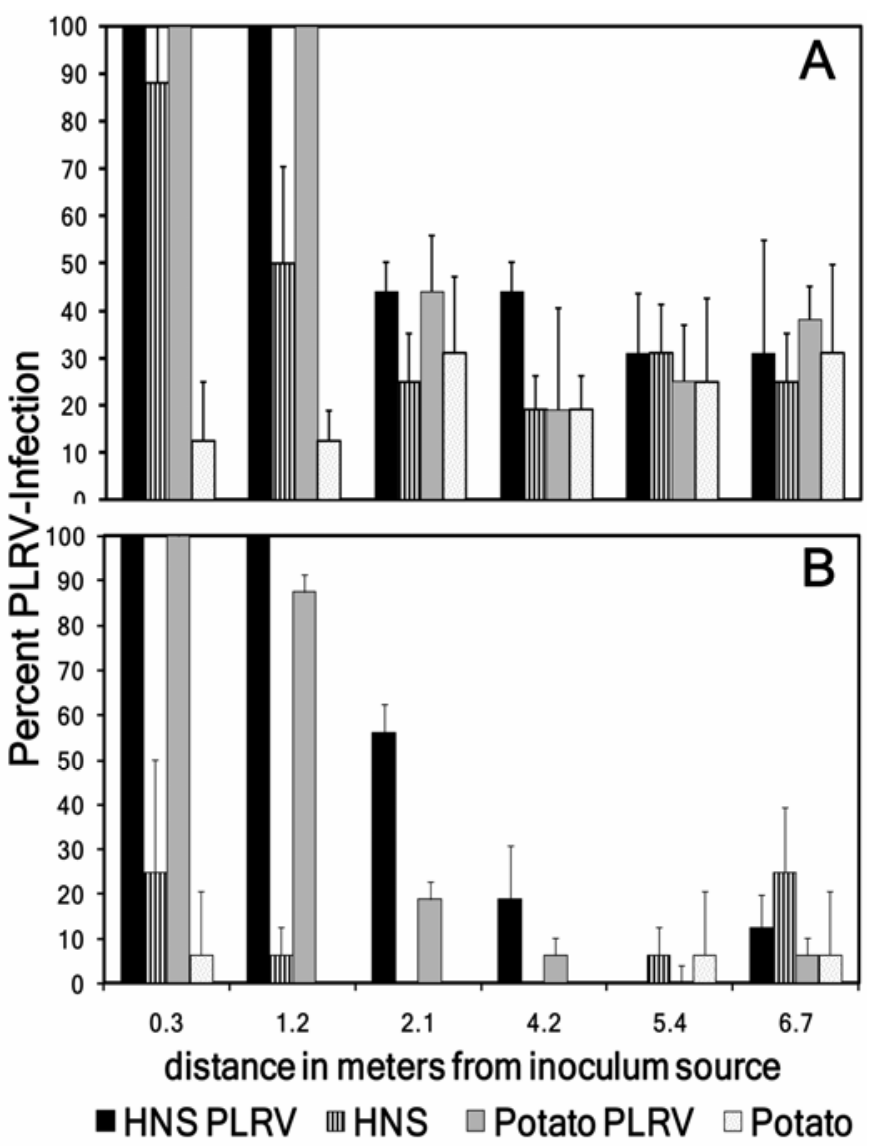

Fig. 6. Spatial Potato leafroll virus (PLRV) spread in potato plots with and without Solanum sarrachoides and PLRV infection in A, 2004 and B, 2005. PLRV infection was determined at weekly intervals at varying distances from the treatment placement. HNS indicates hairy nightshade, S. sarrachoides. 
2004

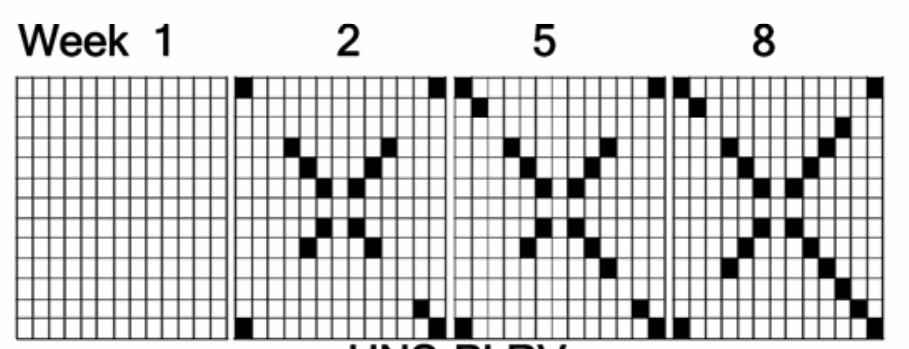

HNS-PLRV

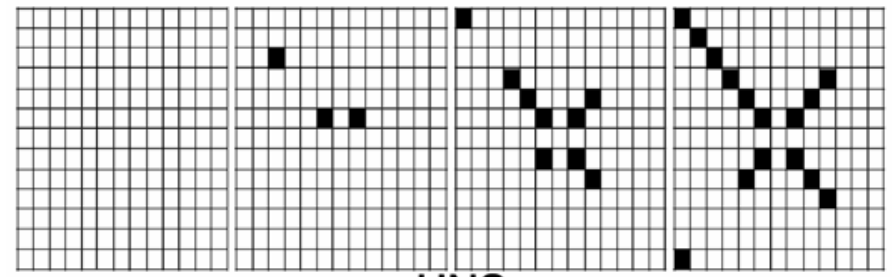

HNS

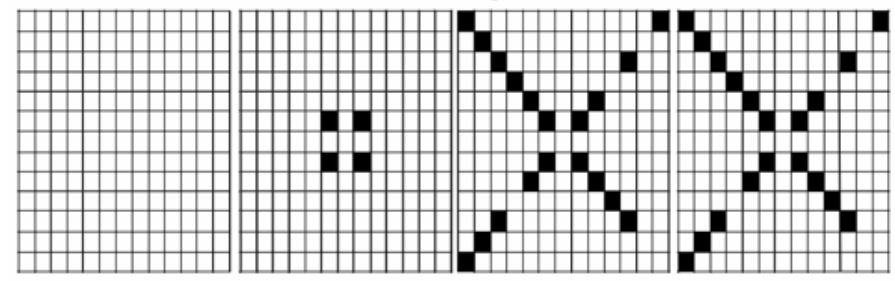

Potato-PLRV

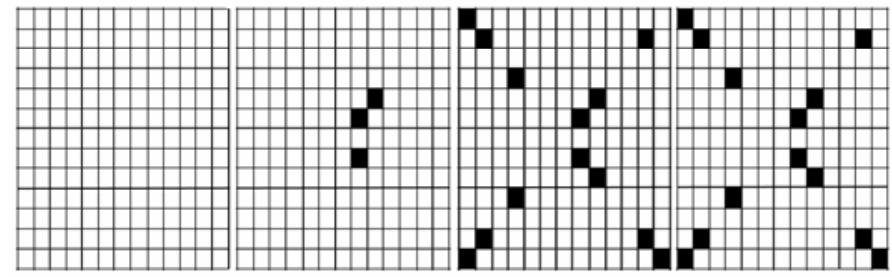

Potato
2005

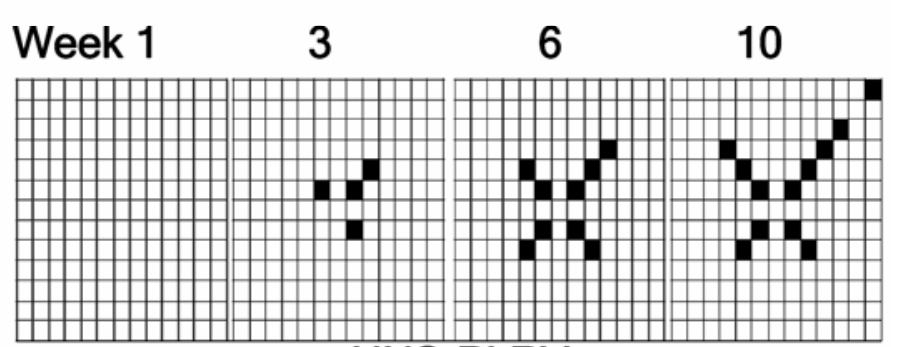

HNS-PLRV

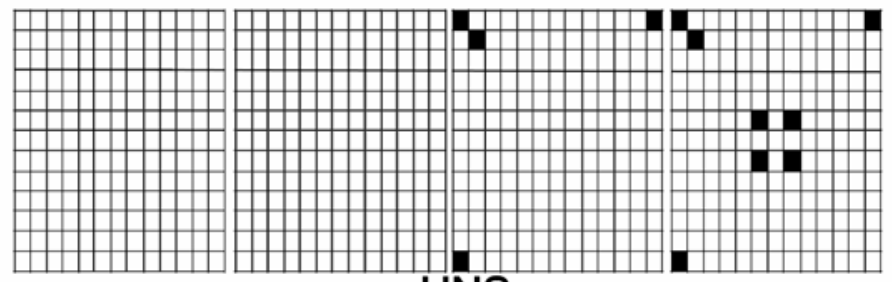

HNS

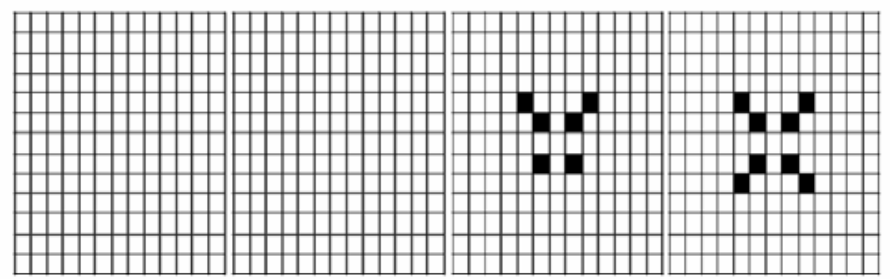

Potato-PLRV

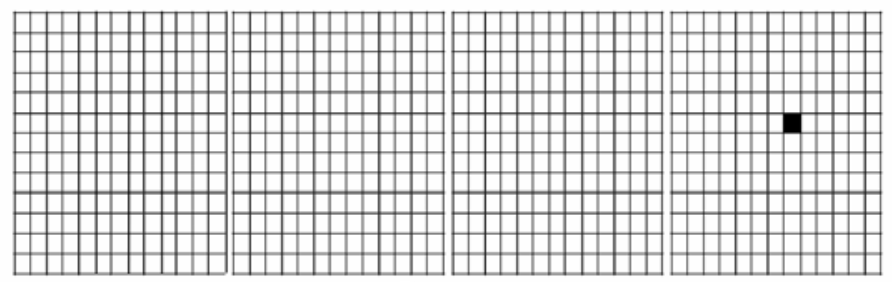

Potato

Fig. 7. Spatial pattern of Potato leafroll virus (PLRV) spread in potato plots with infected and uninfected Solanum sarrachoides and potato at varying time intervals. The treatments were placed in the center of each plot (not shown), and 24 plants (six in each direction) were tagged in an "X like" pattern. PLRVinfected potato plants are indicated by black squares. Data presented are across all replications of S. sarrachoides and potato for 2004 and 2005 . HNS indicates hairy nightshade, $S$. sarrachoides.

vectors a pathogen could seriously complicate disease management. Several solanaceous weeds have already been implicated in potato virus spread $(8,10,13,31,36,37)$.

The ability of $S$. sarrachoides to function as an efficient PLRV inoculum source under typical PNW potato ecosystems is thus demonstrated. Perhaps $S$. sarrachoides could be one of the reasons for commonly observed higher virus incidences despite using high-grade, virus-free potato seed. S. sarrachoides is also a host for a number of other potato viruses (3); this further complicates disease management. S. sarrachoides is very difficult to manage due to its close taxonomic proximity to potato and its phenomenal reproductive capacity (1). Very few selective herbicides are presently available, and their efficiency is still not proven beyond doubt. Broader management solutions encompassing the role of $S$. sarrachoides as a viral inoculum source should be adopted to efficiently manage potato viral diseases in the PNW.

\section{ACKNOWLEDGMENTS}

We thank P. J. S. Hutchinson (PSES, University of Idaho), for providing the hairy nightshade seeds. We thank L. Ewing and D. Brady (Tissue culture facility, University of Idaho) for providing tissue culture potato plantlets; and E. Dotseth, F. A. Cervantes, and H. Libby for technical support. We also acknowledge the editor, A. L. N. Rao, and the two anonymous reviewers of this manuscript for their valuable suggestions. This is Idaho Agricultural Experiment Station manuscript number PSES-0283.

\section{LITERATURE CITED}

1. Alvarez, J. M., and Hutchinson, P. J. S. 2005. Managing hairy nightshade to reduce potato viruses and insect vectors. Outl. Pest Manag. J. 16:249-252.

2. Alvarez, J. M., and Srinivasan, R. 2005. Evaluation of hairy nightshade as an inoculum source for the aphid-mediated transmission of Potato leafroll virus. J. Econ. Entomol. 98:1101-1108.

3. Alvarez, J. M., Stoltz, R. L., Baird, C. R., and Sandvol, L. E. 2003. Potato insects and their management. In: Potato Production Systems. S. Love and J. Stark, eds. University of Idaho Agricultural Communications 2:204-239.

4. Bishop, G. W. 1968. Potato leafroll virus transmission as affected by plant locality. Am. Potato J. 45:366-372.

5. Blackshaw, R. E. 1991. Hairy nightshade (Solanum sarrachoides) interference in dry beans (Phaseolus vulgaris). Weed Sci. 39:48-53.

6. Clark, M. F., and Adams, A. N. 1977. Characteristics of the microplated method of enzyme-linked immunosorbent assay for the detection of plant viruses. J. Gen. Virol. 34:475-483.

7. DiFonzo, C. D., Ragsdale, D. W., Radcliffe, E. B., and Bantarri, E. E. 1994. Susceptibility to potato leafroll virus in potato; Effects of cultivar, plant age at inoculation, and inoculation pressure on tuber infection. Plant Dis. 78:1173-1177. 
8. Donacaster, J. P., and Gregory, P. H. 1948. The spread of virus diseases in the potato crop. Agric. Res. Coun. Rep. Ser. No. 7.

9. Duffus, J. E. 1971. Role of weeds in the incidence of virus diseases. Annu. Rev. Phytopathol. 9:319-340.

10. Dykstra, T. P. 1933. Weeds as possible carriers of leafroll and rugose mosaic of potato viruses by vectors. J. Agric. Res. 47:17-32.

11. Eberlein, C. V., Guttieri, M. J., and Schaffers, W. C. 1992. Hairy nightshade (Solanum sarrachoides) control in potatoes (Solanum tuberosum) with bentazon plus additives. Weed Technol. 6:85-90.

12. Flanders, K. L., Radcliffe, E. B., and Ragsdale, D. W. 1991. Potato leafroll virus spread in relation to densities of green peach aphid (Homoptera: Aphididae): Implications for management thresholds for Minnesota seed potatoes. J. Econ. Entomol. 84:1028-1036.

13. Hanafi, A., Radcliffe, E. B., and Ragsdale, D. W. 1995. Spread and control of potato leafroll virus in the Souss Valley of Morocco. Crop Prot. 14:145-153.

14. Harrington, R., and Taylor, L. R. 1990. Migration for survival: One-scaled population redistribution in an aphid, Myzus persicae. J. Anim. Ecol. 59:1177-1193.

15. Heathcote, G. D., and Broadbent, L. 1961. Local spread of potato leafroll and Y viruses. Eur. Potato J. 4:138-143.

16. Holmes, P. R. 1988. Mobility of apterous grain aphids Sitobion avenae within wheat fields. Entomol. Exp. Appl. 46:275-279.

17. Kassanis, B. 1952. Some factors affecting the transmission of leafroll virus by aphids. Ann. Appl. Biol. 39:157-165.

18. Killick, R. J. 1979. The effect of infection with potato leafroll virus (PLRV) on yield and some of its components in a variety of potato (Solanum tuberosum). Ann. Appl. Biol. 91:67-74.

19. Klingauf, F. A. 1987. Host plant finding and acceptance. Pages 209-224 in: Aphids, Their Biology, Natural Enemies, and Control. Elsevier, New York.

20. Knutson, K. W., and Bishop, G. W. 1964. Potato leafroll virus-Effect of date of inoculation on percent infection and symptom expression. Am. Potato J. 41:227-238.

21. Moran, N. A., and Whitham, T. G. 1990. Differential colonization of resistant and susceptible host plants: Pemphigus and Populus. Ecology 71:1059-1067.

22. Nault, L. R. 1997. Arthropod transmission of plant viruses: A new synthesis. Ann. Entomol. Soc. Am. 90:521-541.

23. Nolte, P., Miller, J. S., Geary, B. D., and Corsini, D. L. 2003. Disease management. In: Potato Production Systems. S. Love and J. Stark, eds. University of Idaho Agricultural Communications 10:153-183.

24. Norris, R. F., and Kogan, M. 2005. Ecology of interactions between weeds and arthropods. Annu. Rev. Entomol. 50:479-503.

25. Ogg, A. G., and Rogers, B. S. 1989. Taxonomy, distribution, biology, and control of black nightshade (Solanum nigrum) and related species in the United States and Canada. Rev. Weed Sci. 4:25-58.

26. Ogg, A. G., Rogers, B. S., and Schilling, E. E. 1981. Characterization of black nightshade (Solanum nigrum L.) and related species in the United
States. Weed Sci. 29:27-32.

27. Purcell, A. H., and Nault, L. R. 1991. Interactions among plant pathogenic prokaryotes, plants and insect vectors. Pages 383-405 in: Microbial Mediation of Plant-Herbivore Interactions. P. Barbosa, V. A. Krischik, and C. G. Jones, eds. Wiley, New York.

28. Quackenbush, L. S., and Andersen, R. N. 1984. Effect of soybean (Glycine max) interference on eastern black nightshade (Solanum ptycanthum). Weed Sci. 32:638-645.

29. Quackenbush, L. S. and Andersen, R. N. 1985. Susceptibility of five species of Solanum nigrum complex to herbicides. Weed Sci. 33:386-390.

30. Ragsdale, D. W., Radcliffe, E. B., and DiFonzo, C. D. 2001. Epidemiology and field control of PVY and PLRV. Pages 237-270 in: Virus and Virus-Like Diseases of Potatoes and Production of Seed-Potatoes. G. Loebenstein, P. H. Berger, A. A. Brunt, and R. H. Lawson, eds. Kluwer Academic Publisher, Dordrecht, The Netherlands.

31. Souza-Diás, J. A. C., Costa, A. S., and Nardin, A. M. 1993. Potato leafroll virus in solanaceous weeds in Brazil explains severe outbreaks of the disease in absence of known potato donor sources. Summa Phytopathol. 19:80-85.

32. Srinivasan, R., Alvarez, J. M., Eigenbrode, S. D., and Bosque-Pérez, N. A. 2006. Influence of hairy nightshade Solanum sarrachoides (Sendtner) and Potato leafroll virus (Luteoviridae: Polerovirus) on the host preference of Myzus persicae (Sulzer) (Homoptera: Aphididae). Environ. Entomol. 35:546-553.

33. Srinivasan, R., Alvarez, J. M., Eigenbrode, S. D., Bosque-Pérez, N. A., and Novy, R. 2008. Effect of an alternate weed host, hairy nightshade, Solanum sarrachoides (Sendtner), on the biology of the two important Potato leafroll virus (Luteoviridae: Polerovirus) vectors, Myzus persicae (Sulzer) and Macrosiphum euphorbiae (Thomas) (Homoptera: Aphididae). Environ. Entomol. 37:592-600.

34. Swensen, K. G. 1968. Role of aphids in the ecology of plant viruses. Annu. Rev. Phytopathol. 6:351-374.

35. Tamaki, G., and Olsen, D. 1979. Evaluation of orchard weed hosts of green peach aphid and the production of winged migrants. Environ. Entomol. 8:314-317.

36. Thomas, J. E. 1993. Alternative hosts and the epidemiology of potato leafroll virus in Queensland. Aust. J. Agric. Res. 44:1905-1916.

37. Thomas, P. E. 2002. First report of Solanum sarrachoides (hairy nightshade) as an important host of potato leafroll virus. Plant Dis. 86:559.

38. Wallis, R. L. 1967. Green peach aphids and spread of beet western yellows in the Northwest. J. Econ. Entomol. 60:313-315.

39. Wallis, R. L. 1967. Some host plants of the green peach aphid and beet western yellows in the Pacific Northwest. J. Econ. Entomol. 60: 904-907.

40. Watt, A. D., and Dixon, A. F. G. 1981. The role of cereal growth stages and crowding in the induction of alatae in Sitobion avenae and its consequences for population growth. Ecol. Entomol. 6:441-447.

41. Wright, G. C., and Bishop, G. W. 1981. Volunteer potatoes as a source of potato leafroll virus and potato virus X. Am. Potato J. 58:603-609. 